\title{
IgE and IgG Antibodies against Bipolaris Australiensis (Ba) in Allergic Fungal Sinusitis
}

\author{
Alonso $A^{\star}$, Rosetti FA, Rodríguez SR, Mouchián K and Albónico JF \\ 2nd Unit of Microbiology, School of Medicine, Buenos Aires University, Argentina
}

*Corresponding author: Alonso A, 2nd Unit of Microbiology, School of Medicine, Buenos Aires University, Argentina, Tel: 54-011-4816-4745; Fax: 54-011-5950-8655; E-mail: sociedad@cientifica.org.ar

Received date: April 20, 2015; Accepted date: June 10, 2015; Published date: June 17, 2015

Copyright: (c) 2015 Alonso A, et al. This is an open-access article distributed under the terms of the Creative Commons Attribution License, which permits unrestricted use, distribution, and reproduction in any medium, provided the original author and source are credited.

\section{Description}

Twelve adult patients suffering an allergic fungal sinusitis were checked by skin-testing with a Ba extract $(13 \mathrm{mg} / \mathrm{mL}$ of proteins detected by the Bradford technique) and their sera were submitted to an ELISA-IgE and IgG methods following Phadebas recommendations [1-7]. Seven patients aged 22 years- 45 years old were atopic (serum IgE $\geq 120 \mathrm{KU} / \mathrm{L}$ ) and suffered chronic allergic rhinitis and asthma; the other 5 patients aged 33 years- 54 years old were not atopic (serum IgE $40 \pm 18 \mathrm{KU} / \mathrm{L}$ ) and no other respiratory complaints [8-19]. The former revealed positive skin tests to the $\mathrm{Ba}$ extract with a wheal \& flare reaction $\geq 5 \mathrm{~mm}$ meanwhile the latter group did not show any positive result and behave as a control group [20-25]. The atopic group was weekly subcutaneous vaccinated with the Ba extract ( $1 \mathrm{mg} /$ dose/week) and after 3 years they revealed significant decrease of their IgE-anti-Ba levels and a marked increase of their IgG-anti-Ba values correlated with a significant improvement of their respiratory condition [26-32] On the other hand, the control group was not vaccinated by ethical considerations, showed no changes in their serum values and suffered the recurrence of their illness [33-41]. The usefulness of specific immune-therapy with $\mathrm{Ba}$ is reinforced for the treatment of allergic fungal sinusitis. An experimental model with guinea-pigs was developed by the daily aerosolization of the protein-peak of $\mathrm{Ba}$ obtained by Sephadex G-50 column fractionation [42-49]. After 12 weeks a typical hypersensitivity pneumonitis was obtained with intense interstitial infiltrates of the lungs, solitary granulomas and foamy cells. It was also checked the presence of IgE-anti-Ba antibodies by the Ovary-Bier's test and of IgG-anti-Ba by the Ouchterlony technique [50-52]. It was demonstrated that the fungus $\mathrm{Ba}$ or Cochliobolus species is a potent antigen that inducing a chronic inflammatory process requires aggressive chirurgical and pharmacological treatments reinforced by immune-therapy $[53,54]$.

\section{References}

1. Albónico JF, Tiraboschi IN (2004) La sinusitis fúngica alérgica. En Temas de Inmunoalergia, tomo 5, Edit CTM, Buenos Aires.

2. Campana N, Alonso A (2004) La poliposis endonasal recidivante. En Temas de Inmunoalergia, tomo 5, Edit CTM, Buenos Aires.

3. Alonso A, Campana NR, Albónico JF, Mouchián K, Kaimen-Maciel I (2009) Aspectos inflamatorios de la poliposis endonasal recidivante (PENAR). Prensa méd argent 96: 197-205.

4. Allphin AL, Strauss M, Abdul-Karim FW (1991) Allergic fungal sinusitis: problems in diagnosis and treatment. Laryngoscope 101: 815-820.

5. Bent JP 3rd, Kuhn FA (1994) Diagnosis of allergic fungal sinusitis. Otolaryngol Head Neck Surg 111: 580-588.

6. Blitzer A, Lawson W (1993) Fungal infections of the nose and paranasal sinuses. Part I. Otolaryngol Clin North Am 26: 1007-1035.
7. Brandwein M (1993) Histopathology of sinonasal fungal disease. Otolaryngol Clin North Am 26: 949-981.

8. Carter KD, Graham SM, Carpenter KM (1999) Ophthalmic manifestations of allergic fungal sinusitis. Am J Ophthalmol 127: 189-195.

9. Clarke SR, Kreutziger KL (1998) Allergic fungal sinusitis. J La State Med Soc 150: 248-252.

10. deShazo RD, Swain RE (1995) Diagnostic criteria for allergic fungal sinusitis. J Allergy Clin Immunol 96: 24-35.

11. Ence BK (1990) Allergic fungal sinusitis. Am J Rhinol 4: 169-173.

12. Folker RJ, Marple BF, Mabry RL, Mabry CS (1998) Treatment of allergic fungal sinusitis: a comparison trial of postoperative immunotherapy with specific fungal antigens. Laryngoscope 108: 1623-1627.

13. Gourley DS, Whisman BA, Jorgensen NL, Martin ME, Reid MJ (1990) Allergic Bipolaris sinusitis: clinical and immunopathologic characteristics. J Allergy Clin Immunol 85: 583-591.

14. Katzenstein AL, Sale SR, Greenberger PA (1983) Allergic Aspergillus sinusitis: a newly recognized form of sinusitis. J Allergy Clin Immunol 72 89-93.

15. Mackenzie JJ (1983) Preliminary report on Aspergillus mycosis of the antrum maxillare. J Hopkins Hospital Bulletin 4: 9-10.

16. Mabry RL, Marple BF, Folker RJ, Mabry CS (1998) Immunotherapy for allergic fungal sinusitis: three years' experience. Otolaryngol Head Neck Surg 119: 648-651.

17. Millar JW (1981) Allergic aspergillosis of the maxillary sinuses. Thorax 36: 710-715.

18. Mc Carthy DS (1971) Allergic bronchopulmonary aspergillosis. Clin Allergy 1: 261-266.

19. Morpeth JF, Rupp NT, Dolen WK, Bent JP, Kuhn FA (1996) Fungal sinusitis: an update. Ann Allergy Asthma Immunol 76: 128-139.

20. Mukherji SF (1998) Allergic fungal sinusitis. Radiology 207: 217-222.

21. Muntz HR (1996) Allergic fungal sinusitis in children. Otolaryngol Clin North Am 29: 185-122.

22. Nash DR (1998) Allergic fungal sinusitis. Immunol Allergy Clin N Am 18: 695-710.

23. Plaignaud M (1791) Observation sur un fungus du sinus maxillaire. J Chir (Paris) 1: 111-116.

24. Sánchez Sánchez BR, Gallardo Rodríguez M, Navarro Chavarría JA Cabrera Muñoz ML (1999) [Allergic fungal sinusitis: recent developments]. Rev Alerg Mex 46: 145-150.

25. Schubert MS, Goetz DW (1998) Evaluation and treatment of allergic fungal sinusitis. I. Demographics and diagnosis. J Allergy Clin Immunol 102: 387-394.

26. Schubert MS, Goetz DW (1998) Evaluation and treatment of allergic fungal sinusitis. II. Treatment and follow-up. J Allergy Clin Immunol 102: 395-402.

27. Waxman JE, Spector JG, Sale SR, Katzenstein AL (1987) Allergic Aspergillus sinusitis: concepts in diagnosis and treatment of a new clinical entity. Laryngoscope 97: 261-266.

28. Schubert MS (2000) Medical treatment of allergic fungal sinusitis. Ann Allergy Asthma Immunol 85: 90-97. 
Citation: Alonso A, Rosetti FA, Rodríguez SR, Mouchián K, Albónico JF (2015) IgE and IgG Antibodies against Bipolaris Australiensis (Ba) in Allergic Fungal Sinusitis. Clin Microbiol 4: 204. doi:10.4172/2327-5073.1000204

Page 2 of 2

29. Ruiz Moreno G (1957) Lecciones de Alergia. López, Etchegoyen (eds.) Buenos Aires.

30. Alonso A, Albónico JF, Tiraboschi NI, Mouchián K, Pionetti $\mathrm{CH}$, et al. (2009) Patogenia e inmunoterapia en la sinusitis fúngica alérgica (SAF) Prensa méd argent 96: 407-410.

31. Bradford MM (1976) A rapid and sensitive method for the quantitation of microgram quantities of protein utilizing the principle of protein-dye binding. Anal Biochem 72: 248-254.

32. Gleich GJ (1975) The radioallergosorbent test : its present place and future in the practice of allergy. Advances in Asthma and Allergy 2: 1-9.

33. Berrens L, Guikers CL, Bruynzeel PL (1979) Possible indirect binding of IgE in house dust RAST. Ann Allergy 43: 38-43.

34. Gleich GJ, Averbeck AK, Swedlund HA (1971) Measurement of IgE in normal and allergic serum by radioimmunoassay. J Lab Clin Med 77: 690-698.

35. Irañeta SG, Duschak VG, Rodríguez SM, Alonso A (2002) Serine proteinases with gelatinolytic activity in an Aspergillus fumigatus allergenic extract. J Investig Allergol Clin Immunol 12: 257-262.

36. Blackley CH (1873) Experimental research on the causes and nature of catarrhus aestivus. Balliere, Tindall \& Cox Ed., London.

37. Hopkins JG (1930) Asthma due to a fungus. JAMA 94: 6-13.

38. Harris LH (1941) Experimental reproduction of respiratory mold allergy. J Allergy 12: 279-286.

39. Pennington ES (1941) A study of clinical sensitivity to airborne moulds. J Allergy 12: 388-396

40. Urbach E (1950) Alergia. In: Salvat (ed.) Barcelona.

41. Hansen K (1950) Alergia clínica. In: Salvat (ed.) Barcelona.

42. Negroni P, Daglio C (1950) Flora micológica del aire en la ciudad de La Plata. Ann Inst Inv Físicas Apl Patol Humana 15: 3-10.
43. Ruiz Moreno G (1944) Alergia y hongos. Ann Inst Inv Físicas Apl Patol Humana 6: 1-7.

44. Bachmann AE, Ruiz Moreno G (1941) Trascendencia de los hongos en la alergia clínica. Ann Inst Inv Físicas Apl Patol Humana 3: 189-192.

45. Giscafré L (1943) Importancia de los hongos en la etiología de las enfermedades alérgicas de la ciudad de Santa Fé. Prensa méd argent 25: 1143-1151.

46. Alonso A, Scavini LM, Mouchián K, Rodríguez SM, Irañeta SG (1990) Antigenicity of Penicillium notatum in animals and in atopic patients. Allergol Immunopathol (Madr) 18: 301-307.

47. Dische Z (1958) The indol method. In: Glick (ed.) Methods of biochemical analysis. Academic Press, New York.

48. OUCHTERLONY O (1958) Diffusion-in-gel methods for immunological analysis. Prog Allergy 5: 1-78.

49. OVARY Z (1958) Immediate reactions in the skin of experimental animals provoked by antibody-antigen interaction. Prog Allergy 5: 459-508.

50. Fink JN (1983) The histopathology of alveolitis. In: Middleton E, Reed CE Ellis EF (eds.) Hypersensitivity pneumonitis. CV Mosby Co, New York.

51. Pepys J (1969) Hypersensitivity diseases of the lungs due to fungi and organic dusts. Monogr Allergy 4: 1-147.

52. Salvaggio JE (1987) Robert A. Cooke memorial lecture. Hypersensitivity pneumonitis. J Allergy Clin Immunol 79: 558-571.

53. Alonso A, Caccuri RL, Scavini LM, Rodríguez SM, Marino GA (1994) Interstitial pneumonitis induced in guinea pigs by Triatoma infestans antigens. J Investig Allergol Clin Immunol 4: 197-202.

54. Alonso A, Mouchián K, Irañeta SG, Rodríguez SR, Albónico JF (2012) Utilidad de la vacunoterapia con Bipolaris australiensis en la sinusitis alérgica fúngica. Prensa méd argent 98: 95-104. 